\title{
内頸動脈血栓内膜剝離術の問題点，特に両側狭窄例について
}

\author{
松本 祐 蔵, 篠原 千恵, 徳 永 浩司, 国 塩 勝三 \\ 守山 英二，加見谷 将 人，則 兼 博
}

\section{Carotid Endarterectomy in Bilateral Stenosis of the Internal Carotid Artery}

Yuzo Matsumoto, M.D., Chie Shinohara, M.D., Koji Tokunaga, M.D.,

Katsuzo Kunishio, M.D., Eiji Moriyama, M.D., Masato Kamitani, M.D., and Hiroshi NoriKane, M.D.

Department of Neurosurgery, Kagawa Central Hospital, Takamatsu, Japan

Summary : Twenty-four carotid endarterectomies (CEA) were performed in 22 cases of internal carotid (IC) stenosis. Nine had bilateral stenosis and 2 underwent CEA on both sides. Preoperative angiography showed other intracranial vascular lesions in $67 \%$ of the bilateral cases, and in $38 \%$ of the unilateral cases. Neurological signs in bilateral cases were major stroke in 3 patients (33\%) and minor stroke in 6 patients $(67 \%)$. On the other hand, minor stroke had occurred in only 8 patients $(62 \%)$ and TIA was presented in $3(33 \%)$ patients with unilateral lesion. Complete occlusion developed on one side in 2 of the bilateral stenosis 4 months after contralateral CEA. These facts suggested that arteriosclerotic change is severe and advanced in bilateral stenosis. And, when bilateral IC stenosis is found to be over $50 \%$ or with ulcer in the case of ischemic neurological deficits, bilateral CEA is recommended before complete occlusion.

Good cross flow was demonstrated preoperatively in $46 \%$ of unilateral IC stenosis, but in bilateral cases only $11 \%$ had good cross flow, and $44 \%$ of them showed poor cross flow. EEG changes such as attenuation of background activity and slow waves following IC clamp were observed in $50 \%$ of bilateral stenosis and $20 \%$ of unilateral stenosis. During endarterectomy with operating microscope, an IC clamp is necessary to continue for about $60 \mathrm{~min}$ and an internal shunt is indicated to prevent hypoperfusion in every case, especially when associated with bilateral stenosis. CEA should be performed in the dominant side first, because this operation is for prophylaxis of further ischemic attack.

\section{はじめに}

近年, 欧米では内頸動脈狭窄に対する血栓内膜剝離術 (CEA)の件数が増加するとともに，有効性や経済性につ いての疑問が多くなり ${ }^{22)}$, 大規模な trial か進行しつつあ $3^{11)}$. 一方, 手術適応の選択, 術中モ二ターや手術手技 の向上などにより，CEA は手術死亡率 1 - $2 \%$, 合併症 2 〜 5\%といわれ2) 5) 20)21), 安全性の高い手術のひとつにな
Key words :

- carotid stenosis

- carotid endarterectomy

- bilateral stenosis

- internal shunt 
SPECTを行った．手術時, stump pressure（9 件）の測定 と脳波 (18 件), 誘発電位 (3 件)のモニターを施行した.

\section{結 果}

22 例の発作型は major stroke（日常生活, 要介助) 3 例, minor stroke（日常生活自立）14 例, TIA 5 例であった。 また, 神経症状として運動麻痺 17 例, 言語障害 9 例, 精 神症状 3 例, 眼症状 1 例がみられた.

内頸動脈病変は血管造影で $50 \%$ 以上の狭乍あるいは潰 瘍形成が認められたものを対象としたが，手術時の狭窄率 は平均 $78.6 \%$ ，潰瘍形成が $62.5 \%$ に認められた. 22 例の うち狭窄病変が片側性であったものが 13 例 $(59 \%)$, 両側 性にみられたものが 9 例 (41\%) あった. 頭蓋内内頸動脈や 中大脳動脈に狭窄その他の血管病変の合併が 11 例にみら れたが, 片側性 13 例のうちでは, 頭蓋内血管病変の合併 は 5 例 $38 \%$ に対し, 両側狭窄例では 9 例中 6 例 (67\%) と 高率に頭蓋内に血管病変を伴っていた (Table 1). 発作型 と内頸動脈病変との関係をみると, major strokeの 3 例全 例, minor stroke 14 例のうち 6 例が両側性狭窄病変をも っていたのに対し, minor strokeの 8 例，TIA の 5 例が 片側性で，明らかに両側狭窄例の方が発作が重症であった

(Table 2).

手術は CEA 22 件, CEA + EC/IC bypass 2 件の計 24 件を施行した。両側手術の 2 例では, 2 回目の手術は初回 手術 4 週間後に行った。実際の手術においては，それぞれ の頸動脈を露出切開後，全例に内シャントを挿入した。内 膜剝離は手術顕微鏡下に行い，できるだけ内腔面を滑らか にし, 内膜切除断端, 特に末梢側では内膜の剝離あるいは 『めくれ』が起こらないように整え, tacking sutureは行 っていない, 手術管理の面では, 術前評価として, 脳血管 造影, 脳波, SPECTを行い, 手術中は, stump pressure の測定，脳波，SEP をモニターした，手術後は高血圧の 予防と抗てんかん剂を投与した. 術前の血管造影に执いて 前交通動脈を介しての cross flow g good（両側内頸動脈 領域が同じように造影される), fair (反対側の造影は注入 側より明らかに少ない), poor (反対側は造影されない)の 3 群に分けた。全体では, good 7 例, fair 9 例, poor 6 例 で cross flowのないものは $27 \%$ のだった。しかし, 両

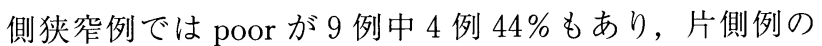
15\%より高率になっていた (Table 3)。また，18 手術にお いて，麻酔導入時より手術終了まで脳波モニターを行った。 頸動脈を露出後, 一時的に内頸動脈血流遮断をして 5 10 分間連続記録した。このうち 6 例 $33 \%$ において, 明らか な徐波化, 低振幅化の変化が遮断 1 2 分後より出現した. また, cross flow と波形変化の関連をみると, 当然のこと ながら波形変化の出現は cross flow の少ない例ほど高率
Table 1 Incidence of intracranial vascular lesions

\begin{tabular}{lll}
\hline & $\begin{array}{l}\text { Unilateral } \\
\text { IC stenosis }\end{array}$ & $\begin{array}{l}\text { Bilateral } \\
\text { IC stenosis }\end{array}$ \\
\hline $\begin{array}{c}\text { With intracranial } \\
\text { lesion }\end{array}$ & $5(38 \%)$ & $6(67 \%)$ \\
$\begin{array}{c}\text { Without intracranial } \\
\text { lesion }\end{array}$ & $8(62 \%)$ & $3(33 \%)$ \\
\hline
\end{tabular}

Table 2 Type of stroke

\begin{tabular}{lll}
\hline & $\begin{array}{l}\text { Unilateral } \\
\text { IC stenosis }\end{array}$ & $\begin{array}{l}\text { Bilateral } \\
\text { IC stenosis }\end{array}$ \\
\hline Major stroke & 0 & $3(33 \%)$ \\
Minor stroke & $8(62 \%)$ & $6(67 \%)$ \\
TIA & $5(38 \%)$ & 0 \\
\hline
\end{tabular}

Table 3 Cross flow on angiogram

\begin{tabular}{lll}
\hline $\begin{array}{l}\text { Cross } \\
\text { flow }\end{array}$ & $\begin{array}{l}\text { Unilateral } \\
\text { IC stenosis }\end{array}$ & $\begin{array}{l}\text { Bilateral } \\
\text { IC stenosis }\end{array}$ \\
\hline Good & $6(46 \%)$ & $1(11 \%)$ \\
Fair & $5(38 \%)$ & $4(44 \%)$ \\
Poor & $2(15 \%)$ & $4(44 \%)$ \\
\hline
\end{tabular}

Table 4 Cross flow and EEG changes during IC clamp (18 cases)

\begin{tabular}{lcccc}
\hline Cross & \multicolumn{2}{c}{ Unilateral stenosis } & \multicolumn{2}{c}{ Bilateral stenosis } \\
\cline { 2 - 5 } flow & Changed & Unchanged & Changed Unchanged \\
\hline Good & 1 & 4 & 0 & 1 \\
Fair & 0 & 3 & 2 & 1 \\
Poor & 1 & 1 & 2 & 2 \\
\hline
\end{tabular}

になり, poorの群では $50 \%$ に達した。また,ここでも両 側狭窄例に異常変化が 50\%にみられ，片側例 20\%と対照 的に多くなっていた (Table 4). 動脈切開時の遮断でシャ ント挿入までに約 5 分間を必要とするが，この間に出現し た脳波変化は，シャント挿入後は直ちに消失した。 SPECT を 8 例 (片側性 4 例, 両側性 4 例) で術前と術後 2 週から 4 週の間に行い比較的検討した. 全例で梗塞部に一 致して血流低下がみられたが，その範讲は $\mathrm{CT}$ 上の梗塞部 より広範囲であった。しかし, 両側性の症例では, 反対側 の血流も低下している症例もあり, その評価は一定してい なかった，手術前後で比較すると 8 例中 4 例で明らかに血 流の改善がみられたが, 残り 4 例では変化がなかった。 stump pressure は 9 例 (片側性 6 例, 両側性 3 例)で内シャ ント設置前に頸動脈を一時遮断して測定した。片側例の平 


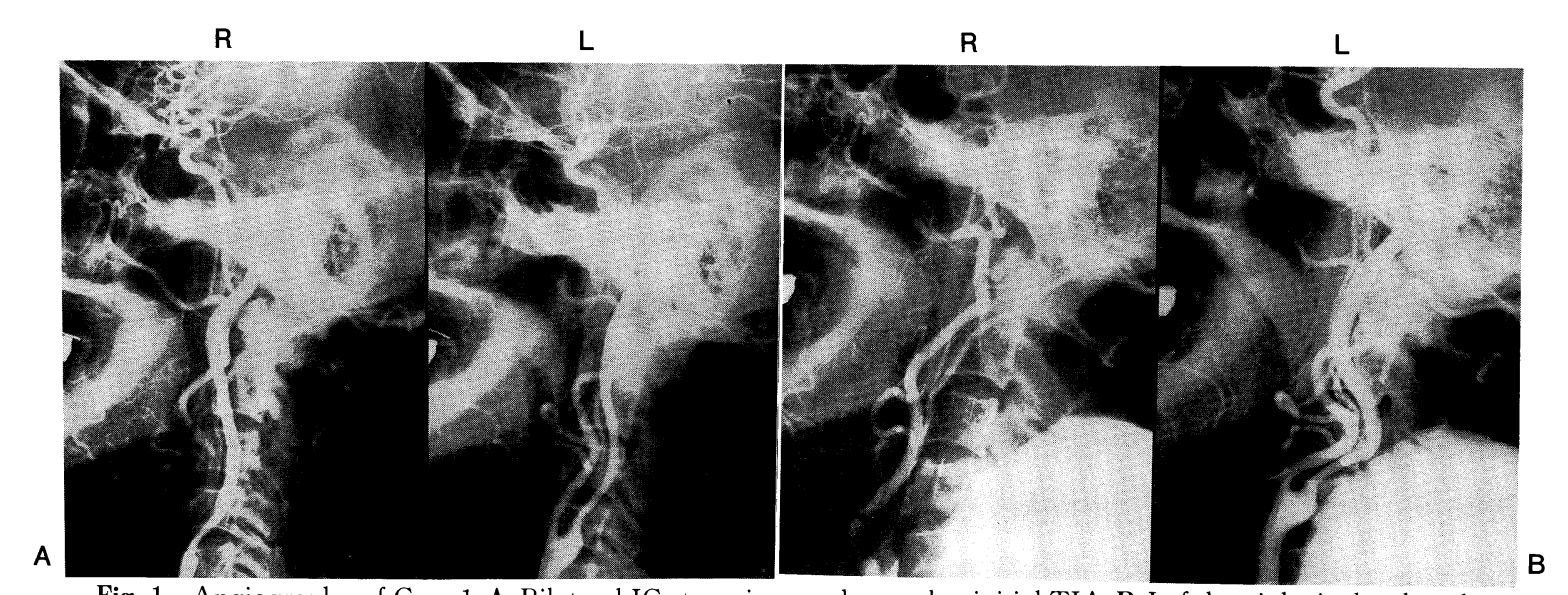

Fig. 1 Angiography of Case 1. A: Bilateral IC stenosis was observed at initial TIA. B: Left hemiplegia developed 4 months later and angiogram showed right IC occlusion.

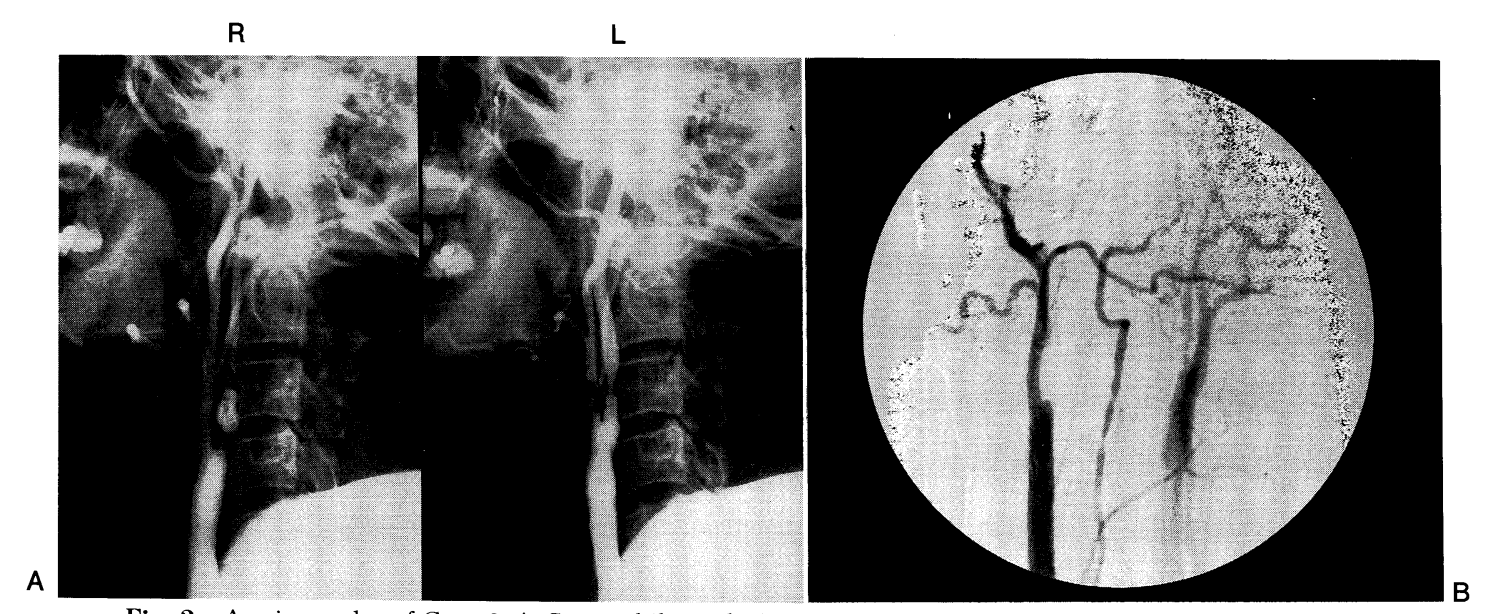

Fig. 2 Angiography of Case 2. A: Severe bilateral IC stenosis on admission for left hemiparesis. B: Repeat angiography (DSA) 1 month after left STA-MCA anastonosis and CEA demonstrated right IC occlusion.

均は $60.3 \mathrm{mmHg}$, 両側例は $50.6 \mathrm{mmHg}$ で両側例が低值 を示したがcross flow, 脳波变化との関連はなかった。 SEP は症例が少なく，結果は省略する.

22 例の手術予後は, 6 力月から 5 年の観察で TIA 症例 では, 症状は全く消失, completed strokeの例では, 症状 の増悪はみられなかった。

\section{症例}

<症例 1> 60 歳, 男性. 左片麻痺の TIA にて発症, 他 院での脳血管造影で両側内頸動脈狭窄を認めた (Fig. 1A) が放置していたところ, 4 力月後に左完全片麻痺となり当 科に入院した. 脳血管造影で, 右内頸動脈の完全閉塞が確 認された(Fig. 1B). 右 STA-MCA 吻合術と, 左 CEAを 行ったが, 症状は改善しなかった。

<症例 2>54 歳, 男性, 左不全片麻痺の minor stroke
にて発症, 両側内頸動脈に潰瘍を伴った高度狭窄を認めた (Fig. 2A). 脳血管造影では前交通動脈を介しての cross flow が不良であった。まず優位側である左側の STAMCA 吻合術と CEA を行った. ところが1 カ月後の脳血. 管造影で右内頸動脈は完全閉塞となっていた (Fig. 2B). このため右側にも STA-MCA 吻合術を施行した. その後 2 年の観察で, 順調に経過している.

\section{考察}

CEA の手術適応は, 虚血性脳血管障害のうち頸部内頸 動脈の高度の狭乍による脳循環障害が認められる症例，も しくは狭窄は軽度であっても血栓表面に潰瘍があり, 栓子 の形成が考えられる症例が一般的と考えられている7)10)20) 21). また, この頸部内頸動脈の狭窄病変のうち, 両側性 の病変についての報告が散見されるようになってきた ${ }^{6)}$ 13) 14). 本報告でも 22 例中 9 例, $41 \%$ が両側性であり, 
Podore ら ${ }^{13)}$ は TIA で CEA を施行された 202 例のうち 95 例 $47 \%$ に対側の内頸動脈狭窄を認めており, Levin $5^{5)}$ も 250 例中 60 例 $24 \%$ の両側例を報告している．両側例にお ける問題点は，1)両側手術の必要性，2)手術順位，3)手術 中の注意点などがあげられる，両側例のうち一側は無症候 性のことが多く，この状態に対する外科的治療の是非につ いては議論の絶えないところである ${ }^{6) 13) 14)}$. Levin ら ${ }^{6)}$ は 2 年間の観察で症状の発現例はなく, TIA が起こってから 手術をすれば良いと述べている，その他の報告でも一般に は, 対側狭窄による発症は $3 \%$ 程度で頻度は高くない4)7) 13). 一方, Schroeder ${ }^{15)}$ は, 片側 CEA を行い, 対側 IC に狭窄あるいは潰瘍のある 135 例の follow-up から 11 例 でTIA あるいは strokeの発生をみており，90\%以上の狭 窄例では対側手術が必要と考えている。 また, Podore ら 13) は片側手術を行った両側狭窄 67 例のうち 14 例 (21\%) に非手術側に一致した神経症状の発現を認め 11 例 (16.5\%)で対側の手術を行ったと報告している.今回の 9 例では片側例と比較して，頭蓋内血管病変の合併が高率で 脳虚血発作の症状も重症で全例 completed strokeを起こ していた。これらのことは，両側例においてさらに閉塞性 の卒中発作を起こしやすい状態にあると考えられる. 現在 の診断技術から, 将来どのような症例に虚血症状が出現あ るいは再発するか不明であるが，われわれの経験した症例 1 では, TIA 発作より 4 力月後, 症例 2 では手術 1 力月後 と非常に短期間で狭窄部が完全閉塞になったのが観察され た.これらのことから, 内頸動脈に高度の狭窄病変の認め られるときは，両側の手術を考慮することが望ましい。つ ぎに左右どちらの側から手術を行うかの点については, TIA，あるいは minor stroke 症例であれば対応側から行 うことが原則であるが, 反対側の狭窄, 潰瘍形成がより高 度な場合など手術側の決定は困難であろう。今回は, 両側 手術症例は 2 例のみであり, この問題については今後検討 が必要と思われる.

手術合併症を減らすため, 手術手技の検討, 改良ととも に, 術中の脳波, 誘発電位のモニターや stump pressure の測定が行われている13)16). 両側狭窄例においては対側 からの cross flow が十分でないものが $44 \%$ もり, 波形 の変化は，両側狭窄例に多くみられ $50 \%$ の例で徐波や低 振幅化が出現した. Blume ら ${ }^{1)}$ は 176 例の CEAにおいて 内頸動脈遮断により 55 例 $31 \%$ に脳波変化を観察している が, 対側の内頸動脈が $90 \%$ 以上の狭窄例で発生しやすか ったと報告している．したがって，血圧の変動をできるだ け少なくして, 脳全体としての循環確保が重要である.こ の目的のために術中, 内シャントが使用されているが, こ れまで，その必要性については多くの意見が言われてきた 7) 16) 19). シャント不要を主張する報告では, 内膜剝離中の
内頸動脈遮断時間が 20 分から 30 分程度で短く ${ }^{19)}$ ，脳虚 血の危険性は少ないが, Blume ら ${ }^{1)}$ は脳波異常を呈した 22 例のうち術後 2 例 (9\%)で虚血性合併症を経験している. 我々の少ない症例ではあるが内シャントの挿入により血流 遮断による脳波変化が正常化され，しかも内シャントによ る塞栓の発生はなく, 実際の手術操作においてもシャント チューブによる支障はなかった，最近では手術顕微鏡を使 用して正確な内膜剥離を行うようになり，少なくとも 30 分以上の時間が必要である. 術中のモニタリング結果から 内シャントの要否を決定すべきとの意見 ${ }^{5)}$ 18) もあるが，現 在のところ遮断中の血流動態を正確に把握する方法のない ことから内シャントは合併症の予防のために有効な処咀で あり,より安全のためには全例に行ってよいと思われる。

特に cross flow の不十分な両側狭窄では, 内頸動脈僬断 後数分で脳波の徐波化の起こるものが多く, 術中の血流確 保に内シャントは不可欠と考えられる.

手術用顕微鏡の普及に伴って, CEAにおいても使用さ れることが多くなり, 剥離断端の処理, 内面の小さな剥離 片の除去ができるようになり, 再狭窄や閉塞などの合併症 が減少し，手術成績が向上してきたものと考えられる ${ }^{817)}$. 我々は, 内膜剥離の段階から顕微鏡を使い, 内面の処理に 細心の注意をはらっており, 特に断端を整ったものにする ことで tacking suture の必要がなくなった.このほか, 手 術合併症の予防のため, 抗凝固剂 $\left.{ }^{3)} 8\right)$, 抗血小板剂 ${ }^{3) 5(17)}$, バルビタール ${ }^{3) 17)}$, 昇圧剂 ${ }^{5)}$ の投与などの対策がなされて いる.

虚血性脳血管障害の術前術後の評価に SPECT が利用さ れ, 血流低下の検出に有効である. SPECTを行った 8 例 全例に梗塞部に一致した低灌流域がみられ，手術適応の決 定には非常に重要であった. しかし, 多発性の梗塞例や両 側性狭窄で左右半球ともに灌流が低下している場合は, 検 査結果の判定が困難であった。 また, 術後 4 例では, 明ら かに血流が改善され, 手術効果の確認に有効であったが, 狭窄の軽度な潰瘍例では当然のことであるが術後の変化は なかった。

今後は, わが国においても脳虚血発作に対する手術適応 症例の選択に関する一定の基準を示し, 厳重な術前術後管 理によって安全性を高めることが大切であろう.

\section{結語}

1. 内頸動脈狭窄 22 例のうち両側狭窄が 9 例 (41\%)にみら れた，両側狭窄例では頭蓋内にも血管病変を伴ってい る場合が多く，脳虚血発作も重症であった。また， 2 例では狭窄が完全閉塞になった。このようなことから， 両側手術が望ましいと思われる.

2. 両側狭窄例では対側からの cross flow が不十分で, 内 
頸動脈血流遮断時に脳波の徐波化することが多く, 術 中の内シャントは不可欠と考えられた.

\section{文献}

1) Blume WT, Ferguson GG, McNeill DK: Significance of EEG change at carotid endarterectomy. Stroke 17: 891897,1986

2) Fode NC, Sundt TM, Robertson JT, et al: Multicenter retrospective review of results and complications of carotid endarterectomy in 1981. Stroke 17: 370-376, 1986

3) Gross CE, Adams HP, Sokoll MD, et al: Use of anticoagulants, electro-encephalographic monitoring, and barbiturate. Cerebral protection in carotid endarterectomy. Neurosurgery 9: 1-5, 1981

4) Johnson N, Burnham SJ, Flanigan DP, et al: Carotid endarterectomy: A follow-up study of the contralateral nonoperated carotid artery. Ann Surg 188: 748-752, 1978

5) Lee KS, Davis $\mathrm{CH}, \mathrm{McWhorter} J \mathrm{M}$ : Low morbidity and mortality of carotid endarterectomy performed with regional anesthesia. J Neurosurg 69: 483-487, 1988

6) Levin SM, Sondheimer FK: Stenosis of the contralateral asymptomatic carotid artery. To operate or not?. Vasc Surg 7: 3-13, 1973

7) Loftus CM, Quest DO: Current status of carotid endarterectomy for atheromatous disease. Neurosurgery 13: 718723,1983

8) Loftus CM, Quest DO: Technical controversies in carotid artery surgery. Neurosurgery 20: 490-495, 1987

9) Muuronen A: Outcome of surgical treatment of 110 patients with transient ischemic attack. Stroke 15: 959-964, 1984

10）中川 翼：虚血性脳血管障害の外科的治療, 脳虚血一基礎 と臨床一，にゅーろん社，東京，1986, pp 190-196

11) North American Symptomatic Carotid Endarterectomy Trial (NASCET) Steering Committee: North American Symptomatic Carotid Endarterectomy Trial. Methods, pa- tient characteristic, and progress. Stroke 22: 711-720, 1991

12) Ojemann RG, Heros RC: Carotid endarterectomy. To shunt or not shunt?. Arch Neurol 43: 617-618, 1986

13) Podore PC, Weese JA, May AG, et al: Asymptomatic con. tralateral carotid artery stenosis: A five-year follow-up study following carotid endarterectomy. Surgery 88: 748752,1980

14) Rile TS, Imparato AM, Mintzer R, et al: Comparison of results of bilateral and unilateral carotid endarterectomy five years after surgery. Surgery 91: 258-262, 1982

15) Schroeder T, Helgstrand UJV, Egeblad MR, et al: Symptomatic carotid lesions after endarterectomy of contralateral carotid artery. Five-year follow up study and prognosis. Arch Surg 122: 795-801, 1987

16）島 健，松村茂次郎，岡田芳和，ほか：頚動脈血栓内膜 摘除術の経験. Neurol Med Chir (Tokyo) 30: 891-897, 1986

17) Spetzler RF, Martin N, Hadley MN, et al: Microsurgical endarterectomy under barbiturate protection: A prospective study. J Neurosurg 65: 63-73, 1986

18) Sundt TM: The ischemic tolerance of neural tissue and the need for monitoring and selective shunting during carotid endarterectomy. Stroke 14: 93-98, 1983

19) Thompson JE: Carotid artery surgery without a temporary indwelling shunt. Arch Surg 115: 1393-1399, 1980

20) Till JS, Toole JF, Howard VJ, et al: Declining morbidity and mortality of carotid endarterectomy, The Waker Forest University Medical Center Experience. Stroke 18: 823-829, 1987

21) Turner DA, Tracy J, Haines SJ: Risk of late stroke and survival following carotid endarterectomy procedures for symptomatic patients. J Neurosurg 73: 193-200, 1990

22) Winslow CM, Solomon DH, Chassin MR, et al: The appropriateness of carotid endarterectomy. N Engl J Med 318: $721-727,1988$ 